\title{
Conceptual Metaphor in Human Communication
}

\author{
Muhammad Surip ${ }^{\mathbf{1}}$, Mulyadi ${ }^{2}$ \\ ${ }^{1}$ Student of Doctoral Program in Linguistics Studies, University of North Sumatera, \\ Indonesia \\ ${ }^{1}$ Lecturer in State University of Medan (Unimed), Indonesia \\ ${ }^{2}$ Lecturer of Doctoral Program of Linguistic Studies, University of North Sumatera, \\ Indonesia \\ ${ }^{1}$ surif@unimed.ac.id ${ }^{2}$ mulyadi@usu.ac.id
}

\begin{abstract}
The study is aimed at investigating the forms of conceptual metaphors using the word 'komunikasi' (communication)in delivering messages. The data were expressions containing the word 'komunikasi'in communication processes, which were in metaphorical formsand collected from various written sources by applying content analysis technique.The results of the study showed that the interpersonal communicationsconveying messagesrelated tothe word 'komunikasi' implying conceptual metaphors can be classified into four domains such as plants, human life, construction and building, and space and time.
\end{abstract}

Keywords: metaphor; communication; interpersonal communication.

\section{Introduction}

Communication is a need of any human being as a realization of their life towards others. Communication can be carried out both directly and indirectly. All human activities must involve communication process through which messages in the forms of ideas, opinions, intentions, etc. are delivered. The messages can either be in written or oral forms. (Mulyana, 2006; Effendy, 2005; Canggara, 2007).

In transmitting messages, intentionally or not, human beings use metaphors. It occurs naturally without us realizing that the words we use are actually metaphorical expressions. This is an interesting phenomenon to be studied, and thus, becomes the primary objective of the study. Let's learn the following example.

(1) The communication analyst is speaking awkwardly.

In example (1), the lingual unit 'analyst', which means 'constantly observing and keeping up attentively' (Kridalaksana, 1982), goes together with the word 'komunikasi' which means 'a process of delivering messages to others'. This implies a comparison between the activities of 'observing' and 'thinking' and interpersonal communication. Such a metaphor may mean as if the activity of observing public communication process took place in mass media. Through the metaphor, the role of 'observing and keeping up' is compared with the activity of message delivering.

Communication metaphors in this study refer to figures of speech - language styles, like analogies, which compare two things directly but in short forms without using the words showing comparison itself.The metaphor of a word that comes before or after the word 'komunikasi' is often applied by a speaker in expressing his meaning even though he himself does not realize that he uses it.

Communication metaphor has not been of linguists' attention although the word 'komunikasi' is very familiar in human life both in oral forms and through mass media. The study intends to further analyze the phenomenon in order to obtain actual and solid data for the sake of linguistic development.

Some research studies concerning metaphor and communication have been conducted previously. Rigas (2000) studied the use of rising pitch in interpersonal communication as a form of communication metaphor. Black (2009) concludes that metaphor has an effect on 
rhetorical persuasion among politicians or to their constituents. The communication performed by politicians in many circumstances involves metaphor in delivering their intentions. Gilas (2008) also found that metaphors were utilized as a rhetorical tool in describing science to public and in other scientific activities. Scientists use metaphors in conveying their messages to people so as to make them understand more easily. Stambuk (1998) asserts that when communicating new knowledge we often use metaphors to allow people to be familiar with any new invention by relating it to another experience. Metaphor, he concludes, plays a significant role in communicating new inventions to public.

This study exposes a variety of data of metaphors that go together with the word 'komunikasi' in the process of message delivery performed by people. It focuses only on the use the word which implies metaphorical meaning.

Linguistics has been studied since the time of Aristoteles. The Greek perceived language as a means of expressing thoughts and feelings in their social interaction. (Purera, 2004:18). Therefore, language was viewed as an effective communication tool to convey ideas and feelings among human beings. The messages can be of literal or figurative meanings.

A study of metaphor is fundamentally related to Semantics and language style. In general, Semantics is defined as a study of meaning. (Lyons, 1989:1). According to Leech (2003:19), in semantic studies there are seven types of meaning such as conceptual, connotative, stylistic, affective, reflection, collocative, and thematic. In this article, the type to be elaborated is only conceptual meaning which will serve as the tool of analysis. Language style is known as style in using language - the way of expressing ideas through language that specifically describes the soul and personality. The power of language style can change and engender a certain connotation. Language style is often applied to boost effect by introducing and comparing an entity with something more general so that it can change and produce a certain connotation. (Tarigan, 1994: 5).

Conceptual metaphor attempts to capture and explain relatively abstract concepts based on man's physical and sensory experience of the world. The type of conceptual metaphor that has been mainly researched is several places which are termed as primary metaphor. (Taylor, 2003); (Searle, 1979). The process of understanding abstract forms by their concrete objects is called conceptual metaphor. (Lakoff, 2000: 5). Conceptual metaphor is a cognitive mechanism which allows one to view and connect an object to another. Thus, it can be said that conceptual metaphor is a cognitive process that expresses a concept with another concept in which the latter corresponds to the former in order to understand a more abstract concept.

In their social life, people often convey figurative or conceptual meaning in their communication process. This is due to the metaphorical nature of language which is unable to portray things directly and requires referents. (Punter, 2007:129). The comparison always refers to the whole context of the message. Therefore, metaphorical formation often considers the relation system between (a) the idea being conveyed, (b) something being imaged, (c) cultural experience, and (d) the context. (Hiraga, 2005; Grothe, 2008). A metaphor is basically a transfer of meaning realized in a metaphorical rule. For example, to mean 'B', something whose meaning is similar to ' $\mathrm{B}$ ' can be used. (Leech, 2003:217). It can be concluded that metaphor is a process of borrowing the concept of a thing to explain the message being delivered.

People in their social life often produce metaphors either verbally or non-verbally. The structure, definition, and process of human thinking are mostly metaphorical. Therefore, for whatever they intend to mean to others, metaphors or metaphorical expressions are likely to appear. 
Metaphors are basically comprised of three elements such as (a) tenor, (b) vehicle, and (c) ground.(Dickins, 2005 : 97). Tenor or target domain (TD) is the concept of an object being described, talked about, analogized, symbolized, and compared. Vehicle or source domain (SD) is the figurative words themselves. Ground or sense $(\mathrm{G})$ refers to the relation of comparison between TD and SD. Through these elements, the concept of metaphor regulates the relation among metaphorical objects and constructs understanding by identifying other objects.

The form of SD is divided into four categories, namely, (a) living things, (b) non-living things, (c) human activities, and (d) natural phenomena. To the first category, Kövecses proposes several kinds of SD such as body parts ('the heart of the city), animal ('wolf-hearted), plants (the root of the problem) and health and illness ('stage fright). (Dickins, 2005). For nonliving objects, Kövecses explicates some other kinds such as construction and building (character building), machinery and tools (the wheels of government), and money and economic transaction (capital flow).In human activities category, examples can also be found in games and sport (a game of life) and cooking and food (spices of life).

Identifications of SD and TD in the concept of metaphor are the referent to analyzing the kinds of metaphors in an utterance or sentence. In this study, Lakoff and Johnson's conceptual metaphor is used. The theory divides into three: (1) structural metaphor, (2) orientational metaphor, and (3) ontological metaphor. (Lakoff \& Johnson, 2003: 7-29).

Conceptual metaphor introduced by Lakoff and Johnson explains that metaphor reflects what we experience, think, and feel in our ordinary life. (2003: 3). Similar to Black's idea, Ungerer and Schmid (1996: 118) claim that metaphor acts as a cognitive tool. In addition, Saeed says that language is a mental sphere and linguistic capacity is built upon special knowledge.(2003: 342). Metaphor does not serve as a tool only of expressing ideas through language but also of thinking about a certain reality. Lakoff and Johnson give such example of conceptual metaphor as "timeismoney" which is not merely a linguistic formation but it must be thought of and conceptualized further so that time can be taken as the target and money as the source being thought of or a valuable and limited commodity. By this perspective, some other expressions such as 'You're wasting my time.', 'Can you give me a few minutes?', and 'How do you spend your time?' came to existence.

Through conceptual metaphor it is obvious how people make effort to construct their ideas. Lakoff and Johnson provide this example 'argument is war'. The metaphor is actually formulated from casual expressions based on what people experience when they make arguments such as 'I've never won an argument with him.', 'I demolished his argument.', and 'He shot down all of my arguments.' These expressions contain meanings which imply that argument is war. Such formulation is constructed when the arguing takes place. People put themselves in a battle or war when they argue. They always do their best to win and never like to lose so that such phrases as attacking by arguments, defending positions, breaking down an argument, winning over the opponents, applying a strategy might appear. In a real war, some expressions like 'defending the state', 'attacking the enemy', 'defeating the enemy', etc. are often used.

Kovecses (2006: 116-126) says conceptual metaphor reflects what is perceived, experienced, and thought by people about their real world. The reflection goes into their semantic memory and can be exposed at any time. To use it, one only needs to activate the memory and realize it in a verbal form, and, therefore, metaphorical expressions sometimes are of preferences because they bring a content of higher priority and attention, and the emotion resembles the speaker's intention. 
Metaphor has two components: (1) target, and (2) domain. According to Lakoff and Johnson (2003: 20); Kovecses (2006), target is more abstract and, conversely, domain is more concrete. To be able to understand what is in a metaphor, it is necessary to recognize similar characteristics between the target and the source. By comparing the characteristics, the basic idea of the metaphor can be uncovered.

The choice of a source for a certain target is made based on bodily experience when taking the condition being felt. For example, Kovecses (2006: 117) says that the expression'affection is warmth'is derived from an experience that when one feels loved by others he can also feel warmth.

It is previously said that conceptual metaphor indicates a process taking place in a sphere to explain an entity based on feeling, experience, and thought which are real and or imagined to be real by means of other entity that is more concrete and can be visualized or experienced by the body. Therefore, according to Kovecses (2006:128), there are three components that must be clarified such as source domain, target domain, and metaphorical base. The three are fundamental in conceptual metaphor. Source domain has more concrete characteristics and serves as the point of departure in describing the target. For example, in a metaphor 'life is a journey', it can be inferred that 'life', which is abstract in nature, is compared with the word 'journey' to make it easier to understand. People understand the meaning of 'life' which is the target by identifying any similar characteristic to 'journey' as the source. The similar characteristics in both components function as the basis of the metaphor; in a journey one has a destination, may deal with obstacles, sets the distance and in life he has to face hardship, gains improvement, sets a purpose, etc.

As per Lakoff and Johnson (Cruse, 2004: 201), conceptual metaphor is analyzed as a process of cognitive conceptualization which depends on three elements such as (1) source domain, (2) target domain, and (3) mapping or correspondence. The term correspondence consists of two categories: (a) ontological correspondence, referring to the nature of the relation between the two entities, and (b) epistemic correspondence, referring to our knowledge that relates the entities.

Lakoff and Johnson also propose two concepts of abstract and concrete. The abstract concept is built up systematically from the concrete concept through metaphorical process. They term the abstract concept as conceptual metaphor which is defined as 'generalized metaphoricalformulas tha tcharacterize specific abstraction'. To conclude, the so-called conceptual metaphor is a specific abstraction realized in generalized metaphors.

\section{Methodology}

The study used linguistic data sorted out from the data collected in the process of delivering and receiving messages in interpersonal communication or in other printed and electronic media. There were three stages of the study such as data collection, data analysis, and presentation of the results. The technique used was content analysis. The collected data were analyzed to find out their metaphorical forms.

The method of data analysis applied was referential method which was used to show and compare the referents or meanings conveyed in source domain and target domain. In addition, content analysis by using inferential technique (Sudaryanto, 1993: 61) was also applied to determine how cognitive processes occurred during the production of the metaphors to relate the source with the target domain and identify the origin of the metaphor.The data analysis was 
performed both during and post collection. In general, the analysis went through three phases: (a) description, (b) interpretation, and (c) explanation.

\section{Discussion}

This section tries to expose the data of how the word 'komunikasi', which entails metaphorical meaning, is used in communication process. For some data, people might not be aware that the word 'komunikasi' they use in their daily communication has a metaphorical nature. The linguistic expressions must first be interpreted to get their meanings even though people can always translate them literally.

From the collected data, it was found that the word 'komunikasi' which contains metaphorical meaning was influenced by the media or other people in a communication. This study, therefore, categorized the kinds of conceptual metaphors. Conceptual metaphor, according Lakoff (1987) is dependent upon cognition resulted from mental construction, and one which is based on comparison of cross-conceptual domains in a system of concepts having the nature and structure of metaphor. (Punter, 2007. Davidson, 1979).

One of the steps in mapping out the concepts is classifying those which conceptualize communication metaphor into domains. The classification of the data is a process which determines the system of metaphors which exist.

\subsection{Identifying Communication Metaphors}

In terms of communication metaphors, twenty three data of communication metaphors were collected from various sources as presented below.

a) Communication metaphors related to plants. The metaphors were realized by the phrasespohon komunikasi (=communication tree), buah komunikasi (lit. fruit of communication, =communication outcome), cabang komunikasi (=communication branch)andakar komunikasi (=communication root).

b) Communication metaphors associated with construction and building. The metaphors were realized by the phrasesrumah komunikasi(=house of communication), pintu komunikasi (=door of communication), jendela komunikasi (=window of communication), and membangun komunikasi (=building communication).

c) Communication metaphors related to human life. The metaphors were realized by the phrases komunikasi perasaan (=communication of feelings), komunikasi hati (=heart communication), melek komunikasi (=communication literate), ritual komunikasi (=communication ritual), kegagalan komunikasi (=communication failure), bahasa komunikasi (=language of communication), pengamat komunikasi (=communication analyst), and fasilitas komunikasi (communication facilities).

d) Communication metaphors associated with time and space. The metaphors were realized by the phrases daya komunikasi (=communication power), komunikasi resmi (=formal communication), komunikasi massal (=mass communication), kesenjangan komunikasi (=communication gap), komunikasi multikultural (=multicultural communication), komunikasi legal dan komunikasi ilegal (=legal and illegal communication), komunikasi kelas atas (=high-class communication), and komunikasi kelas bawah (=low-class communication).

The results of the identification were then elaborated into the concepts mapped out by way of cross-domain. 


\subsection{Conceptual Mapping of Communication Metaphors}

The results above reveal a fact that conceptualizations of other concepts within communication metaphors in interpersonal communication exist. Lakoff and Johnson assert that to be able to explain conceptual metaphors, an analysis of conceptual mapping is required. Conceptual mapping helps explain the system of concepts realized in the classifications of the communication metaphors.

\section{A. Communication metaphors in the domain of plants}

The data mapped out into the domain of plants are:

(1) Para menteri harus berusaha memahami pohon komunikasi agar kedekatan dengan presiden terus terbangun.(=The ministers must try to understand the communication tree so that a close relation with the President can be maintained.)

(2) Pencalonan Edy dan Ijeck menjadi calon Gubernur Sumatera Utara merupakan buah komunikasi dari upaya tiga partai besar di Indonesia. (=The candidacy of Edy and Ijeck to be North Sumatra's governor and vice governor is (lit. fruit of communication) an outcome of communication by three big political parties in Indonesia)

(3) Agar relasi cepat terbangun kita membutuhkan pemahaman berbagai cabang komunikasi yang dapat kita lakukan. (=To build a relation immediately we need to understand various communication branches which we can use.)

(4) Perbedaan karakter antara suami dan istri telah menjadi akar komunikasi perceraian mereka. (=Character differences between the husband and his wife have been the communication root of their divorce.)

Table 1. The Conceptual Mapping of Communication Metaphors in the Domain of Plants

\begin{tabular}{ll}
\hline \multicolumn{1}{c}{ Target } & \multicolumn{1}{c}{ Source } \\
\hline $\begin{array}{l}\text { The communication pattern can build } \\
\text { emotional intimacy between the sender and } \\
\text { receiver. }\end{array}$ & $\begin{array}{l}\text { Pohon komunikasi } \\
\text { (communication tree) }\end{array}$ \\
\hline $\begin{array}{l}\text { Building communication with each other } \\
\text { will raise a good relation. }\end{array}$ & $\begin{array}{l}\text { Buah komunikasi (lit. fruit of } \\
\text { communication) } \\
\text { (communication outcome) }\end{array}$ \\
\hline $\begin{array}{l}\text { In order to immediately build a relation a } \\
\text { variety of communication } \\
\text { techniques/methods are needed. }\end{array}$ & $\begin{array}{l}\text { Cabang komunikasi } \\
\text { (communication branches) }\end{array}$ \\
\hline $\begin{array}{l}\text { The basis for communication building } \\
\text { needs to be understood to stimulate a good } \\
\text { relation. }\end{array}$ & $\begin{array}{l}\text { Akar komunikasi } \\
\text { (communication root) }\end{array}$ \\
\hline
\end{tabular}

The noun phrases pohon komunikasi, buah komunikasi, cabang komunikasi, and akar komunikasi share similar concepts being compared in interpersonal communications. Pohon komunikasi makes use of plants to be its comparison with any communication pattern which helps build and maintain emotional intimacy with the addressee. Plants consist of stem, twigs, leaves and fruits, which implies that a speaker is supposed to understand all types of communication pattern that can help build and strengthen the relation with the addressee. Without such understanding, it will be difficult to grow emotional intimacy between the 
interlocutors. Akar komunikasi symbolizes the basis for building a good relation through the message delivery. Being the source for a communication to occur, the elements involved must first be understood to avoid and reduce misunderstanding. The elements are sender, message, media, receiver, and feedback. Knowing the elements is the prerequisite of any interpersonal communication to take place smoothly and to achieve the target. The phrase akar komunikasi takes plants as a comparison with the object being talked about. Akar (root) represents the fundamental element of any plant and serves as the main concern in the establishment of good communication.

Buah komunikasi is a metaphor symbolizing that a plant is ready to be harvested. Buah (the fruit) which the farmer expects from a plant is one that should be achieved optimally. However, there are always two possibilities: a success or a failure. As a comparison, buah komunikasirepresents the result of a communication process. Each party involved must expect that a good result should be obtained from a good relation in the communication. Cabang komunikasiis a metaphor showing that a plant has branches and twigs although communication basically requires specific elements to occur. It should be understood in this context that cabang komunikasi refers to all effective methods or techniques applied by interlocutors to achieve the target.

\section{B. Communication metaphors related to construction and building}

The data containing this kind of metaphor are mapped as follows:

(5) PDIP telah lama menjadi rumah komunikasi Jokowi dalam membangun Indonesia yang lebih mandiri dalam ekonomi, politik dan budaya.(=PDIP have long been a communication house for Jokowi to develop Indonesia to be more independent in economy, politics, and culture.)

(6) Kahiyang menjadi pintu komunikasi bagi Golkar untuk mendampingi Jokowi dalam Pilpres 2019 mendatang. (Kahiyang acts as adoor of communication for Golkar to win position of Vice President Candidate to run in 2019's election.)

(7) Ilmu menjadi jendela komunikasidunia dalam mengejar hidup sukses. (Knowledge is the window of communication to the world for anyone to be successful.)

(8) Rakyat sulit membangun komunikasi dengan kepala desa, karena gaya kepemimpinannya yang otoriter.(The villagers find it difficult to build communication with their chief because of his authoritarian leadership.)

Table 2. Conceptual mapping of communication metaphor associated with construction and building

\begin{tabular}{ll}
\hline \multicolumn{1}{c}{ Target } & \multicolumn{1}{c}{ Source } \\
\hline $\begin{array}{l}\text { A communication center is necessary to be } \\
\text { a media of establishing good relation. }\end{array}$ & $\begin{array}{l}\text { rumah komunikasi } \\
\text { (communication house) }\end{array}$ \\
\hline $\begin{array}{l}\text { A path opener of a relation should be } \\
\text { understood so that the message being } \\
\text { conveyed can hit the target. }\end{array}$ & $\begin{array}{l}\text { pintu komunikasi } \\
\text { (door of communication }\end{array}$ \\
\hline $\begin{array}{l}\text { Any medium of communication should be } \\
\text { taken into account to build a relation. }\end{array}$ & $\begin{array}{l}\text { jendela komunikasi } \\
\text { (window of communication) }\end{array}$ \\
\hline $\begin{array}{l}\text { Establishing an effective communication } \\
\text { requires hard work. }\end{array}$ & $\begin{array}{l}\text { membangun komunikasi } \\
\text { (building communication) }\end{array}$ \\
\hline
\end{tabular}


The communication metaphors above are applied as the realizations of conceptualizations to establish good relation in communication. Rumah komunikasi makes use of construction and building to compare with a spot of dialogue. Rumah komunikasi is interpreted as a place and media in which communication between sender and receiver takes place. Pintu komunikasi symbolizes an opener (a trigger) for a communication and good relation to occur. A good relation is affected by how a communication is initiated, including sender's characters, message, media, or receiver. If an initiated communication does not produce any response - observed from acceptability and intention for follow-up - it is unnecessary to continue the process. The non-living thing 'door' in this domain is taken as a path opener of the establishment of good relation to agree to continue the relation.

The phrase jendela komunikasi is a symbol used to represent a medium which means that in order to be successful one must be knowledgeable. In other words, knowledgemust be recognized as a medium of seeing outside the house toopen the way to achieve success. The phrase membangun komunikasi represents an effort to build good relation or communication between the sender and the receiver. By this phrase, the meaning of the word 'build' as 'trying to construct good relation by using communication' is compared with its meaning as 'delivering messages to others through various media'. Such metaphor is often used in both direct and indirect communication, which implies an effort to re-manage or re-build relation with others through communication.

\section{Communication metaphors associated with human life}

The data obtained in relation to human life are as follows:

(9) Rudi hingga sekarang masih mengalami kesulitan dalam mengkomunikasikan perasaannya kepada calon istrinya padahal mereka akan segera menikah mei mendatang. (Rudi has been striving hard to communicate his feelings to his prospective wife although they are going to be married in May)

(10) Komunikasi hati antara ibu dan balitanya telah terbangun sejak dilahirkan.(The heart communication between the mother and her baby has been worked out since he was born)

(11) Dosen harus melek komunikasi agar dapat menunjang tugas dan tanggungjawabnya sebagai pengajar profesional. (Lecturers must be communication literate to support their duties as professional teachers)

(12) Banyak calon anggota DPR yang aktif melakukan ritual komunikasi kepada para normal di Kulonprogo Jawa Timur. (A lot of candidates of parliament members do communication rituals with some psychics in Kulonprogo, East Java)

(13) Kegagalan komunikasi kesehatan yang dilakukan dokter di Indonesia telah mendorong masyarakat untuk berobat ke negara jiran Malaysia.(The communication failures of health by Indonesian doctors have caused people to get medical services in Malaysia)

(14) Bahasa komunikasi Gubernur dan Wakil Gubernur Sumatera Utara selalu menjadi kendala dalam mencapai target pembangunan nasional. (The communication language of the Governor and Vice Governor of North Sumatra Province has been a serious obstacle in achieving the national development targets)

(15) Pengamat komunikasi itu berbicara tidak santun dalam forum ilmiah di kampus. (The communication analyst spoke impolitely in a scientific forum in the university) 
Budapest International Research and Critics in Linguistics and Education (BirLE) Journal

Volume 2, No 4, November 2019, Page: 120-132

e-ISSN: 2655-1470 (Online), p-ISSN: 2655-2647 (Print)

www.bircu-journal.com/index.php/birle

emails: birle.journal@gmail.com

birle.journal.qa@gmail.com

(16) Mereka menggunakan berbagai fasilitas komunikasi untuk meyakinkan rakyat agar memilihnya pada pemilu legislatif nanti. (They use various communication facilities to convince voters to elect them in the upcoming legislative election)

Table 3. Conceptual mapping of communication metaphors associated with human life

\begin{tabular}{ll}
\hline \multicolumn{1}{c}{ Target } & \multicolumn{1}{c}{ Source } \\
\hline $\begin{array}{l}\text { A good relation is reflected in smoother } \\
\text { way of delivering feelings. }\end{array}$ & $\begin{array}{l}\text { komunikasi perasaan } \\
\text { (communication of feelings) }\end{array}$ \\
\hline $\begin{array}{l}\text { The realizations of close relation are } \\
\text { touches, smiles, mutual needs. }\end{array}$ & $\begin{array}{l}\text { komunikasi hati } \\
\text { (heart communication) }\end{array}$ \\
\hline $\begin{array}{l}\text { Any human being has to utilize all } \\
\text { available media in performing a } \\
\text { communication. }\end{array}$ & $\begin{array}{l}\text { melek komunikasi } \\
\text { (communication literate) }\end{array}$ \\
\hline $\begin{array}{l}\text { Communication habits will be the initial } \\
\text { activities in building communication. }\end{array}$ & $\begin{array}{l}\text { ritual komunikasi } \\
\text { (communication ritual) }\end{array}$ \\
\hline $\begin{array}{l}\text { Communication failures must } \\
\text { have causes. }\end{array}$ & $\begin{array}{l}\text { kegagalan komunikasi } \\
\text { (communication failure) }\end{array}$ \\
\hline $\begin{array}{l}\text { Style of speaking in a communication will } \\
\text { have an impact to the result. }\end{array}$ & $\begin{array}{l}\text { bahasa komunikasi } \\
\text { (communication language) }\end{array}$ \\
\hline $\begin{array}{l}\text { Mass media analyst is one of } \\
\text { communication experts' concerns. }\end{array}$ & $\begin{array}{l}\text { pengamat komunikasi } \\
\text { (communication analyst) }\end{array}$ \\
\hline $\begin{array}{l}\text { A variety of communication tools need to } \\
\text { be used to guarantee effective } \\
\text { communication process. }\end{array}$ & $\begin{array}{l}\text { fasilitas komunikasi } \\
\text { (communication facilities) }\end{array}$ \\
\hline
\end{tabular}

These metaphorical phrases komunikasi perasaan, komunikasi hati, melek komunikasi, ritual komunikasi, kegagalan komunikasi, bahasa komunikasi, pengamat komunikasi, and fasilitas komunikasi are the realizations of communication activities among human beings in creating a good relation. Komunikasi perasaan is an expression of exposing what is in one's heart. He sometimes really wishes to speak out his inner voice but often the meaning captured might be different. The data of communication metaphors showing feelings compare communication with creatures. All human beings have had such experience, especially when they try to express their deep intention to other people they know well or begin to institute a good relationship with. Exposing the inner voice can be carried out in direct way or through actions. For example, a woman might remain silent when asked by her parents about an engagement. Silence in this context means her acceptance of her boyfriend's proposal.

Komunikasi kesehatan is conceptualized through a communication process which can have an effect on a patient's recovery. The phrase compares a communication process with health, which is interpreted as an effort to help cure the patient from his illness. Through an effective communication the patient may feel motivated and supported to raise confidence for his recovery. A doctor who has such a skill can increase patient's optimism. Komunikasi hati is conceptualized in touches/affection, smiles, mutual needs between the sender and receiver in a communication process. A good relationship is perceived thorough not onlyoral messages but also non-verbal language or body language. A mother may only need to give a gentle touch 
and smile to her baby to deliver her good message. The metaphors use body part as a comparison. Ritual komunikasi makes use of 'human activity' as its comparison by a message transmission which can shape habit to strengthen one's true self. The activity of communication habit becomes the origin of a good relationship. Melek komunikasi is conceptualized as utilizing various communication media in delivering messages.

Bahasa komunikasi is conceptualized as speaking styles in communication. Everyone has his own style which is a result of cultural practices. Speaking style can also be learned and trained.One involved in a communication needs to adjust his style with the message, situation and condition in order to bring an effect. Fasilitas komunikasiis conceptualized as communication tools. The metaphor uses non-living thing as a comparison to explain the media used in the communication. Various communication facilities can help achieve the success of a communication. A wrong choice of facility can influence the final result of the communication. The phrase pengamat komunikasi is conceptualized as an expert who actively acts as an analyst of mass media. The realization is a concern exhibited by the expert about the reality of the message in mass media to show his contribution for the good of all people in general.

\section{Communication metaphors associated with space and time}

The data of this domain are mapped as below.

(17) Rektor memiliki daya komunikasi yang tinggi dalam membangun karakter civitasnya untuk berkomitman memajukan kampus. (The rector has a high communication power to improve the characters of his academic community so that they boost their commitment to advancing the university)

(18) WhatsApp telah menjadi komunikasi resmi diberbagai elemen masyarakat. (WhatsApp has been an official communication among the societies)

(19) Kesenjangan komunikasi telah menjadi kendala bagi orang tua dalam menghantarkan anak ke pintu sukses masa depannya. (Communication gap has been an obstacle for parents to guide their children achieve success)

(20) Media sosial telah menjadi komunikasi masal dalam mempromosikan produknya kepada publik. (Social media have functioned as mass communication to promote products to customers)

(21) Rudi sangat mahir melakukan komunikasi kelas atas dan komunikasi kelas bawah dalam membangun relasi kepada semua pihak. (Rudi is so good at performing high-class and low-class communications in building his relations to all elements.)

(22) Seorang direktur harus memahami bentuk komunikasi legal dan komunikasi ilegaldiperusahaan yang di pimpinnya. (A director has to understand both legal and illegal communications in the company he leads)

(23) Presiden Jokowi aktif melakukan komunikasi multikultural dalam upaya menyatukan rakyat Indonesia. (President Jokowi actively builds multicultural communications to unite the people of Indonesia)

Table 4. Conceptual mapping of communication metaphors related to time and space

Target Source




\begin{tabular}{ll}
\hline $\begin{array}{l}\text { Message conveyance has power which } \\
\text { functions to ensure the success of a } \\
\text { communication process. }\end{array}$ & $\begin{array}{l}\text { daya komunikasi } \\
\text { (communication power) }\end{array}$ \\
\hline $\begin{array}{l}\text { Formal media as tools of message } \\
\text { transmission need to be controlled. }\end{array}$ & $\begin{array}{l}\text { komunikasi resmi } \\
\text { (formal communication) }\end{array}$ \\
\hline $\begin{array}{l}\text { Delivering message openly requires constant } \\
\text { drill to minimize errors and mistakes during } \\
\text { a communication. }\end{array}$ & $\begin{array}{l}\text { komunikasi masal } \\
\text { (mass communication) }\end{array}$ \\
\hline $\begin{array}{l}\text { Communication process performed by } \\
\text { human beings cannot be separated from } \\
\text { communication problem which surrounds it. }\end{array}$ & $\begin{array}{l}\text { kesenjangan komunikasi } \\
\text { (communication gap) }\end{array}$ \\
\hline $\begin{array}{l}\text { There exists a specific communication } \\
\text { pattern between its leaders and members in } \\
\text { an organization. }\end{array}$ & $\begin{array}{l}\text { komunikasi kelas atas dan komunikasi } \\
\text { kelas bawah } \\
\text { (high-class and low-class communica- } \\
\text { tions) }\end{array}$ \\
\hline $\begin{array}{l}\text { A communication process in an organization } \\
\text { involves formal and informal manners. }\end{array}$ & $\begin{array}{l}\text { komunikasi legal dan komunikasi } \\
\text { ilegal } \\
\text { (legal and illegal communications) }\end{array}$ \\
\hline $\begin{array}{l}\text { Message being exchanged in a } \\
\text { communication process is about differences } \\
\text { in a culture or cross-culture. }\end{array}$ & $\begin{array}{l}\text { komunikasi multikultural } \\
\text { (multicultural communication) }\end{array}$ \\
\hline
\end{tabular}

The metaphors related to time and space as mapped out above are daya komunikasi, komunikasi resmi, komunikasi masal, kesenjangan komunikasi, komunikasi kelas atas dan komunikasi kelas bawah, komunikasi legal dan komunikasi ilegal and komunikasi multikultural. Daya komunikasi is conceptualized as having a power which functions to guarantee the success of a communication process. In a well-established communication both the sender and receiver must prove that each acts properly. If they do not share a similar vision, the positive energy between them will not turn to be a strong base in the relationship. Komunikasi resmi is conceptualized as formal media in formal activities in formal organizations such as found in formal letters or other media. Human activity, in this context, becomes a comparison in formal delivery of a message. Komunikasi massal is abstracted as conveying message openly to public. The metaphor comparesthe delivery with society or public as media. It compares human activity with a collective message delivery in various assemblies. Kesenjangan komunikasi is abstracted as communication problem which is considered an obstacle by all involved interlocutors. The problem is perceived to be a hindrance in achieving effective communication process. It may arise from sender, message, receiver, media, or feedback. A sender takes a more important role in dealing with the problem which restrains an effective process.

Komunikasi kelas atas is conceptualized as a communication occurring among leaders, superiors, or authorities in a government or organization. Meanwhile, komunikasi kelas bawah symbolizes that communication performed by ordinary people or subordinates in a government or organization. This metaphor functions as a comparison with one's ability to run his business by taking advantage of his relations with both authorities and ordinary people. Komunikasi legal dan komunikasi ilegal are conceptualized as formal and informal media in an organization or government. Komunikasi legalrefers to formal media of delivering message, whereas, 
komunikasi ilegal is conceptualized as an informal one such as through social media. Formal communication in an organization is a vertical communication between a superior and a subordinate. Meanwhile, informal communication is one which is naturally performed by all members of an organization to maintain solidity. Komunikasi multikultural is conceptualized as a message being exchanged which is concerned with differences in a culture or inter-culture and using human activity as its comparison. Komunikasi multikultural is meant to be an effort to communicate interculturally in order to sustain a good relationship.

\section{Conclusion}

Referring to the findings and discussion of the study, the conceptual metaphors in which the word 'komunikasi' is used can be classified into four domains: (1) plants, (2) human life, (3) construction and building, and (4) time and space. The findings and the analysis can help readers understand about conceptual metaphors which are not yet familiar to public. Messages in communication metaphors applied in human communication are often used only to increase popularity of their use. In fact, the metaphors are of conceptual kinds in which messages categorized into source and target exist.

The study only analyzes conceptual metaphors in the process of message transmission in interpersonal communication both directly and indirectly. It must contain weakness as it deals with human communication metaphors using the word 'komunikasi', data of which are very limited.

\section{References}

Black, Charteris, 2009. Metafora dan Komunikasi Politik. Jurnal Metaphor and Discourse Journal.

Black, Max.1996. "Metaphor," in Models and Metaphors, Ithaca, NY: Cornell University Press.

Cangara, Hafid. 2008. Pengantar Ilmu Komunikasi. Jakarta. Rineka cipta.

Davidson, Donald. 1979. What Metaphors Mean, in Onmetaphor, edited by S. Sacks. Chicago: University of Chicago Press.

Dickins, James. 2005. Two Models for Metaphor Translation. Target.

Effendy, Onong Uchjana. 1997. Ilmu Teori dan Filsafat Komunikasi. Bandung: PT. Cita Aditya Bakti

Giles, 2008. Motives for Metaphor in Scientefic and Technical Communication. Published by Baywood Publishing Co.

Glucksberg, Sam, Patricia Gildea, and Howard Bookin 1982 "On Understanding Non literal Speech: Can People Ignore Metaphors?" Journal of verbal learning and verbal behavior 21: 85-98.

Goatly, Andrew.1997. The Language of Metaphors. London : Routledge.

Grothe, Mardy. 2008. Never Methapor I Didn't Like: A comprehensive Compilation

Hiraga, Masako K. 2005. Methapor and Iconicity. New York: Paigrave Mac Milan

Keraf, Gorys. 1994. Diksi dan gaya bahasa. Jakarta: PT Gramedia Pustaka Utama.

Keysar, Boaz .1989. "On the Functional Equivalence of Literaland Metaphorical Interpretations in Discourse," Journal of Memory and Language 28: 375-85. 1989b. Atlanta, GA.

Kovecses, Zoltan. 2002. Methapor: A Practical Introduction. New York: Oxford 
Kridalaksana, Harimurti. 1982. Kamus Linguistik. Jakarta: Gamedia.

Lakoff, George, and Mark Johnson.1980. Metaphors We Live. Chicago: University of Chicago Press.

Leech, Geoffrey.2003. Semantik. Yogyakarta. Pustaka Pelajar

Leezenberg, Michiel. 2001. Contexts of Metaphor. University of Amsterdam,

Levin, Samuel. 1977. The Semantics of Metaphor. Baltimore: Johns Hopkins. University Press. Lyons, John.1989. Semantics. New York: Cambridge University Press.

Miller, George.1979 "Images and Models: Similes and Metaphors," in Metaphor and Thought, edited by A. Ortony. Cambridge: Cambridge University Press.

Mulyana, Deddy. 2008. Ilmu Komunikasi: Suatu Pengantar. Bandung. PT. Remaja Rosdakarya.

Parera, J.D. 2004. Teori Semantik. Jakarta: Erlangga.

Punter, David. 2007. Methapor. New York: Routledge.

Rigas, D.I. 2000. Penggunaan Nada Meningkat Sebagai Metafora Komunikasi. Dept. Of Comput, IEEE Publications.

Searle, John.1979.Metaphor," in MetaphorandThought, editedby A. Ortony. Cam bridge: Cambridge University Press.

Saeed, John I. 2003. Semantics. SecondEdition. Oxford: SpeechActs: An Essay in the Philosophy of Language. London: Cambridge University Press.

Stambuk, A. 1998. Metaphor in Scientific Communication. Meta; Journal Destraducteurs. Kroasia.

Sudaryanto. 1993. Metode dan Aneka Teknik Analisis Bahasa. Pengantar Penelitian Wahana Kebudayaan Secara Linguistis. Yogyakarta. Duta Wacana University Press.

Tarigan, H.G. 1985. Pengantar gaya bahasa. Bandung: Angkasa.

Taylor, John R. 2003. Linguistic Categorization. United States of America: Oxford University Press Inc. 